Check for updates

Cite this: RSC Adv., 2018, 8, 30902

\title{
Biosorption and bioaccumulation characteristics of cadmium by plant growth-promoting rhizobacteria $\uparrow$
}

\begin{abstract}
Xingjie Li, (D) Dongbo Li, Zhenning Yan and Yansong Ao*
Plant growth-promoting rhizobacteria (PGPR) not only promote growth and heavy metal uptake by plants but are promising biosorbents for heavy metals remediation. However, there exist arguments over whether extracellular adsorption (biosorption) or intracellular accumulation (bioaccumulation) play dominant roles in Cd(॥) adsorption. Therefore, three cadmium-resistant PGPR, Cupriavidus necator GX_5, Sphingomonas sp. GX_15, and Curtobacterium sp. GX_31 were used to study bioaccumulation and biosorption mechanisms under different initial $\mathrm{Cd}(॥)$ concentrations, using batch adsorption experiments, desorption experiments, scanning electron microscopy coupled with energy dispersive X-ray (SEM-EDX) spectroscopy, transmission electron microscopy (TEM), and Fourier-transform infrared (FTIR) spectroscopy. In this study, with the increase of the initial $\mathrm{Cd}(\Perp)$ concentrations, the removal efficiency of strains decreased and the adsorption capacity improved. The highest $\mathrm{Cd}(\Perp)$ removal efficiency values were $25.05 \%, 53.88 \%$, and $86.06 \%$ for GX_5, GX_15, and GX_31 with $20 \mathrm{mg} \mathrm{l}^{-1}$ of Cd(॥), while the maximum adsorption capacity values were $7.97,17.13$, and $26.43 \mathrm{mg} \mathrm{g}^{-1}$ of GX_5, GX_15, and GX_31 with $100 \mathrm{mg} \mathrm{l}^{-1}$ of $\mathrm{Cd}(\Perp)$. Meanwhile, the removal efficiency and adsorption capacity could be ordered as GX_31 > GX_15 > GX_5. The dominant adsorption mechanism for GX_5 was bioaccumulation (50.66$60.38 \%$ ), while the dominant mechanisms for GX_15 and GX_31 were biosorptions $(60.29-64.89 \%$ and 75.93-79.45\%, respectively). The bioaccumulation and biosorption mechanisms were verified by SEMEDX, TEM and FTIR spectroscopy. These investigations could provide a more comprehensive understanding of metal-bacteria sorption reactions as well as practical application in remediation of heavy metals.
\end{abstract}

Received 24th July 2018

Accepted 25th August 2018

DOI: $10.1039 / c 8 r a 06270 f$

rsc.li/rsc-advances

\section{Introduction}

Remediation of heavy metal-contaminated soil has received much attention due to heavy metals' adverse effects on plants, animals, microorganisms, and humans. Among hazardous metals, cadmium (Cd) is of particular concern because it is difficult to degrade, accumulates easily, and is highly toxic. ${ }^{1}$ It has been demonstrated that a small amount of $\mathrm{Cd}$ (II) in the food chain can cause health risks in humans. ${ }^{2}$

Physicochemical approaches such as filtration, ion exchange, chemical precipitation, and solvent extraction are widely used to remove heavy metals from the environment. ${ }^{3}$ However, these applications are mostly ineffective, expensive, and nonspecific, especially when concentrations of heavy metals are low. ${ }^{4}$ Therefore, it is imperative to find an efficient, cost-effective alternative. The use of microbiological biomass, including bacteria, ${ }^{5}$ fungi, ${ }^{6,7}$ and yeast,${ }^{8}$ is increasingly accepted

School of Agriculture and Biology, Shanghai Jiao Tong University, Shanghai 200240, China. E-mail: aoys@sjtu.edu.cn; Tel: +86-13916002737

$\dagger$ Electronic supplementary information (ESI) available. See DOI: $10.1039 / \mathrm{c} 8 \mathrm{ra} 06270 \mathrm{f}$ in metals removal due to the large and well defined surface area of biomass, its high binding affinity, its environmental friendliness, and its low cost. ${ }^{9}$

Microbial remediation takes place mainly through biosorption or bioaccumulation mechanisms. ${ }^{\mathbf{1 0}}$ Biosorption is a passive-process, metabolism-independent extracellular adsorption, where heavy metal ions are passively adsorbed onto components of the cell surface. ${ }^{\mathbf{1 1}}$ Generally, biosorption contains the following mechanisms: physical entrapment (physical adsorption), ion exchange, and complexation in functional groups, ${ }^{12,13}$ which may be independently or synergistically involved. ${ }^{\mathbf{1 4}}$ Bioaccumulation, on the other hand, is an active-process, metabolism-dependent intracellular accumulation. ${ }^{15}$ It is a more complex process entailing many occurrences, including localization of the metal within specific organelles, metallothionein binding, and efflux pumping. ${ }^{14,16}$ Microorganisms show promise for the removal of heavy metals from polluted environments through both bioaccumulation and biosorption processes.

Bioaccumulation and biosorption have been extensively studied by some researchers. ${ }^{\mathbf{1 7 - 1 9}}$ However, there have been arguments on whether bioaccumulation or biosorption plays 
a dominant role in $\mathrm{Cd}(\mathrm{II})$ adsorption. ${ }^{20-22}$ Little work has been done to investigate the predominant mechanisms (bioaccumulation and biosorption) involved in the reduction of $\mathrm{Cd}(\mathrm{II})$ toxicity of Gram-positive and Gram-negative bacteria at a time. Moreover, many researchers did not take metal concentrations into consideration during the adsorption process. ${ }^{23,24}$

The objectives of the present work were: (1) to investigate the capacities of $\mathrm{Cd}(\mathrm{II})$-resistant PGPR, i.e., Cupriavidus necator GX_5 (CP002878), Sphingomonas sp. GX_15 (MF959440), and Curtobacterium sp. GX_31 (MF959445), for Cd(II) adsorption under the same experimental conditions; (2) to analyze surface interaction between static biomass and Cd(II) by means of SEMEDX, TEM, and FTIR analysis; (3) to elucidate the main adsorption mechanism (bioaccumulation or biosorption) of bacteria for $\mathrm{Cd}$ (II) under different initial Cd(II) concentrations using batch adsorption experiments; and (4) to provide new insight into Cd-resistant PGPR's potential use for bioremediation of contaminated environments.

\section{Materials and methods}

\subsection{Bacterial strains and culture medium}

The PGPR used in this study were the Gram-negative strains Cupriavidus necator GX_5 (CP002878) and Sphingomonas sp. GX_15 (MF959440) and the Gram-positive strain Curtobacterium sp. GX_31 (MF959445), isolated in a 60 year-old lead-zinc core from rhizosphere soil of local (Guangxi, China) dominant plants, with an average Cd(II) concentration of $59.43 \mathrm{mg} \mathrm{kg}^{-1}$. Bacteria were cultured in Luria-Bertani (LB) broth medium and maintained at $28{ }^{\circ} \mathrm{C}$.

\subsection{Preparation of the biosorbent}

Strains were incubated at $\mathrm{pH} 6.0$ in LB medium on a rotary shaker at $28{ }^{\circ} \mathrm{C}$ and $180 \mathrm{rpm}$. The cultural cells were harvested (exponential phase) and washed three times with sterile water, then separated by centrifugation at $10000 \times g$ for $10 \mathrm{~min}$, collected, and lyophilized overnight in a Labconco freeze dryer. ${ }^{25}$ The dried cells were ground to fine powder and used as biosorbent.

\subsection{Cd(II) solution}

All chemicals used in this study were of analytical grade and solutions were prepared using $\mathrm{ddH}_{2} \mathrm{O}$. Stock solutions of $\mathrm{Cd}(\mathrm{II})$ $\left(1000 \mathrm{mg} \mathrm{l}^{-1}\right)$ were prepared by dissolving $\mathrm{CdCl}_{2} \cdot 2.5 \mathrm{H}_{2} \mathrm{O}$ in $\mathrm{ddH}_{2} \mathrm{O}$. The initial $\mathrm{pH}$ of the working solutions was adjusted to 6.0 for $\mathrm{Cd}(\mathrm{II})$ binding experiments by the addition of $0.1 \mathrm{~mol} \mathrm{l}^{-1}$ $\mathrm{HCl}$ and $\mathrm{NaOH}$ solution.

\subsection{Adsorption of $\mathrm{Cd}(\mathrm{II})$ by biosorbent}

Adsorption experiments were conducted at $28{ }^{\circ} \mathrm{C}$ in batches with $0.02 \mathrm{~g}$ of resting cells in $50 \mathrm{ml}$ plastic tubes containing $20 \mathrm{ml}$ of 20,50 , and $100 \mathrm{mg} \mathrm{l}^{-1}$ working solution. The mixture was shaken for $2 \mathrm{~h}$ and then centrifuged at $10000 \times g$ for $10 \mathrm{~min}$. Then the concentration of $\mathrm{Cd}(\mathrm{II})$ in the supernatant was analysed via inductively coupled plasma. The difference between the initial $\mathrm{Cd}(\mathrm{II})$ concentration and the remaining ion concentration was assumed to have been adsorbed by cells. The removal efficiency value adsorption (\%) for $\mathrm{Cd}(\mathrm{II})$ of the biomass was calculated using the following eqn (1):

$$
\operatorname{Adsorption}(\%)=\frac{C_{0}-C_{\mathrm{eq}}}{C_{0}} \times 100
$$

where $C_{0}$ and $C_{\mathrm{eq}}$ are the initial and equilibrium metal concentration in the supernatant $\left(\mathrm{mg} \mathrm{l}^{-1}\right)$, respectively. The adsorption capacity ( $\mathrm{AC}, \mathrm{mg} \mathrm{g}^{-1}$ ) was calculated from eqn (2):

$$
\mathrm{AC}\left(\mathrm{mg} \mathrm{g}^{-1}\right)=\frac{\left(C_{0}-C_{\mathrm{eq}}\right) \times V}{m}
$$

where $C_{0}$ and $C_{\text {eq }}$ are the same as in eqn (1), $m(\mathrm{~g})$ is the weight of cell sorbent, and $V(\mathrm{~L})$ is the volume of working solution. Control experiments without strains were carried out in order to determine whether the plastic tubes adsorb Cd(II) from the solution. All experiments were conducted in triplicate.

\subsection{Desorption of $\mathrm{Cd}(\mathrm{II})$ by biosorbent}

Desorption of $\mathrm{Cd}(\mathrm{II})$ from previously loaded resting cells was studied by using $\mathrm{ddH}_{2} \mathrm{O}, 1.0 \mathrm{~mol} \mathrm{l}^{-1}$ of $\mathrm{NH}_{4} \mathrm{NO}_{3}$, and $0.1 \mathrm{~mol} \mathrm{l}^{-1}$ of EDTA- $\mathrm{Na}_{2}$ as eluent. ${ }^{12,23}$ Briefly, biosorption can be described under three categories: (1) physical entrapment, which binds metals weakly to the cell surface and is easily susceptible to desorption by water; (2) ion exchange with $\mathrm{K}^{+}, \mathrm{Ca}^{2+}, \mathrm{Na}^{+}$, and $\mathrm{Mg}^{2+}$ on the cell wall, which can be desorbed using $\mathrm{NH}_{4} \mathrm{NO}_{3}$; and (3) complexes with functional groups, which can be desorbed via EDTA. Remaining metals are considered to be bioaccumulated and cannot be desorbed via EDTA.

Desorption experiments were conducted in batches with $0.02 \mathrm{~g} \mathrm{Cd}(\mathrm{II})$-loaded cell biosorbent in $50 \mathrm{ml}$ plastic tubes containing $20 \mathrm{ml}$ of each eluent mentioned above. After $2 \mathrm{~h}$ of reaction, shaking at $28{ }^{\circ} \mathrm{C}$, supernatants were analysed after centrifugation for $\mathrm{Cd}(\mathrm{II})$ concentration. Adsorption capacities for each of the above-mentioned categories was calculated from the amount of $\mathrm{Cd}(\mathrm{II})$ adsorbed in the strains and from the final $\mathrm{Cd}(\mathrm{II})$ concentration in the desorption solution. Meanwhile, bioaccumulation and biosorption capacity were also evaluated. The same procedure was repeated three times.

\subsection{SEM-EDX observation}

The surface characteristics of strains before and after interaction with $\operatorname{Cd}(\mathrm{II})\left(20,50\right.$, and $\left.100 \mathrm{mg} \mathrm{l}^{-1}\right)$ were studied using a SEM (Sirion 200, USA). For SEM analysis, the prepared cell biosorbent was fixed with $2.5 \%$ glutaraldehyde at $4{ }^{\circ} \mathrm{C}$ overnight. The fixed sample was then smeared on the coverslip, air dried, dehydrated using a gradient series with ethanol, and sputter-coated with gold. ${ }^{26}$ Energy dispersive X-ray (EDX) of the samples was simultaneously analyzed.

\subsection{TEM observation}

For transmission electron microscopy (TEM), strains were prepared without and with $\mathrm{Cd}(\mathrm{II})$ inoculations $(20,50$, and $100 \mathrm{mg} \mathrm{l}^{-1}$ ). The prepared samples were fixed with $2.5 \%$ glutaraldehyde at $4{ }^{\circ} \mathrm{C}$ for $6 \mathrm{~h}$, washed with $0.1 \mathrm{M}$ PB solution, 
fixed in $1 \%$ osmium tetroxide for $2 \mathrm{~h}$, dehydrated, and embedded in resin as described by Tyagi and Malik. ${ }^{27}$ The pretreated samples were then cut into thin slices, stained, and observed using a TEM (Tecnai G2 spirit Biotwin, USA) at magnifications of $30 \mathrm{k}$, $68 \mathrm{k}$ and $98 \mathrm{k}$.

\subsection{Fourier transformed infrared spectroscopy observation}

The functional groups of $\mathrm{Cd}(\mathrm{II})$-loaded and unloaded cells were analysed using a Fourier-transform infrared (FTIR) spectrometer (Nicolet 6700, USA) at room temperature. All infrared spectra were recorded over the range of $4000-400 \mathrm{~cm}^{-1}$ with a resolution of $4 \mathrm{~cm}^{-1}$. Sample disks were made from $2 \mathrm{mg}$ of cells encapsulated in $200 \mathrm{mg}$ of $\mathrm{KBr}$.

\subsection{Statistical analysis}

Data were subjected to analysis of variance and represented as the mean \pm standard deviation. Pairwise differences among treatments were tested using a mean separation test (least significant difference) at $p=0.05$. All statistical analyses were performed using SAS8.1 software.

\section{Results and discussion}

\subsection{Cd(II) adsorption by biosorbent}

Under optimal conditions ( $\mathrm{pH}$ : 6.0; reaction time: $6 \mathrm{~h}$; biomass dosage: $1.0 \mathrm{~g} \mathrm{l}^{-1}$ ) based on the preliminary data, the batch adsorption experiments were conducted with initial $\mathrm{Cd}(\mathrm{II})$ concentrations: 20, 50, and $100 \mathrm{mg} \mathrm{l}^{-1}$. The largest Cd(II) removal efficiency was $86.06 \%$, for Curtobacterium sp. GX_31 under the initial concentration of $20 \mathrm{mg} \mathrm{l}^{-1}$; while the minimal removal efficiency was $7.98 \%$, for Cupriavidus necator GX_5 with $100 \mathrm{mg} \mathrm{l}^{-1} \mathrm{Cd}$ (II) treatment. It was obviously observed that a significant difference in $\mathrm{Cd}(\mathrm{II})$ adsorption existed among the three strains-more specifically, GX_31 > GX_15 > GX_5 ( $p<$ 0.05) - given the same amount of Cd(II) (Fig. 1A). In the study, biomass dosage $\left(1.0 \mathrm{~g} \mathrm{l}^{-1}\right)$ was measured by weighing the freezedried fine powder of biosorbent, which was time-consuming but more accurate than methods in some previous studies. ${ }^{28-30}$
Meanwhile, the batch adsorption experiments were conducted using resting biomass rather than growing cells in medium. Considering the different growth rates of strains in medium, it is inappropriate to compare adsorption efficiency and capacity between strains. However, it makes sense that removal efficiency varied among strains based on their own adsorption or defence mechanisms. ${ }^{\mathbf{1 0}}$

In Fig. 1A, we also see that removal efficiency was significantly higher at lower concentrations than at higher concentrations for the same strains, which is in accordance with other studies. ${ }^{15,29,31}$ At low concentrations, the ratio of the moles of Cd(II) to the available surface area was low, leaving a large number of binding sites free for $\mathrm{Cd}$ (II) interactions and resulting in high adsorption efficiency. ${ }^{32}$ On the contrary, at high concentrations of $\mathrm{Cd}(\mathrm{II})$, a lack of sufficient free binding sites resulted in low removal efficiency. ${ }^{33}$

Similarly, the three strains showed a range of adsorption capacities when treated under the same Cd(II) concentrations: GX_31 > GX_15 > GX_5 $(p<0.05)$ (Fig. 1B). In considering identical strains, adsorption capacity was stronger at higher concentrations than that at lower concentrations (Fig. 1B). The strongest and weakest adsorption capacities were $26.43 \mathrm{mg} \mathrm{g}^{-1}$ for GX_31 at $100 \mathrm{mg} \mathrm{l}^{-1}$ of Cd(II) and $5.01 \mathrm{mg} \mathrm{g}^{-1}$ for GX_5 at $20 \mathrm{mg} \mathrm{l}^{-1}$, respectively. High initial concentrations could provide an effective force for driving metal ions to interact with finite metal binding sites, prompting adsorption by biomass strains. ${ }^{34}$ However, the adsorption capacity of the biosorbent would reach a saturation value with the increase of initial metal concentrations due to limited binding sites. ${ }^{26}$

\subsection{Desorption of $\mathrm{Cd}(\mathrm{II})$ from loaded cell biosorbent}

The amounts of Cd(II) desorbed from GX_5, GX_15, and GX_31 by water, $\mathrm{NH}_{4} \mathrm{NO}_{3}$, and EDTA- $\mathrm{Na}_{2}$ were investigated and displayed in Fig. 2, which shows that 5.67-8.95\% and $0.97-3.93 \%$ of Cd(II) adsorbed by GX_15 and GX_31, respectively, was desorbed by water; $56.09-59.66 \%$ and $71.20-75.70 \%$, respectively, was desorbed by $\mathrm{NH}_{4} \mathrm{NO}_{3}$; and $60.29-64.89 \%$ and $75.93-79.45 \%$ by EDTA-Na ${ }_{2}$ (Fig. 2B and C). In comparison, 21.21-30.34\% of
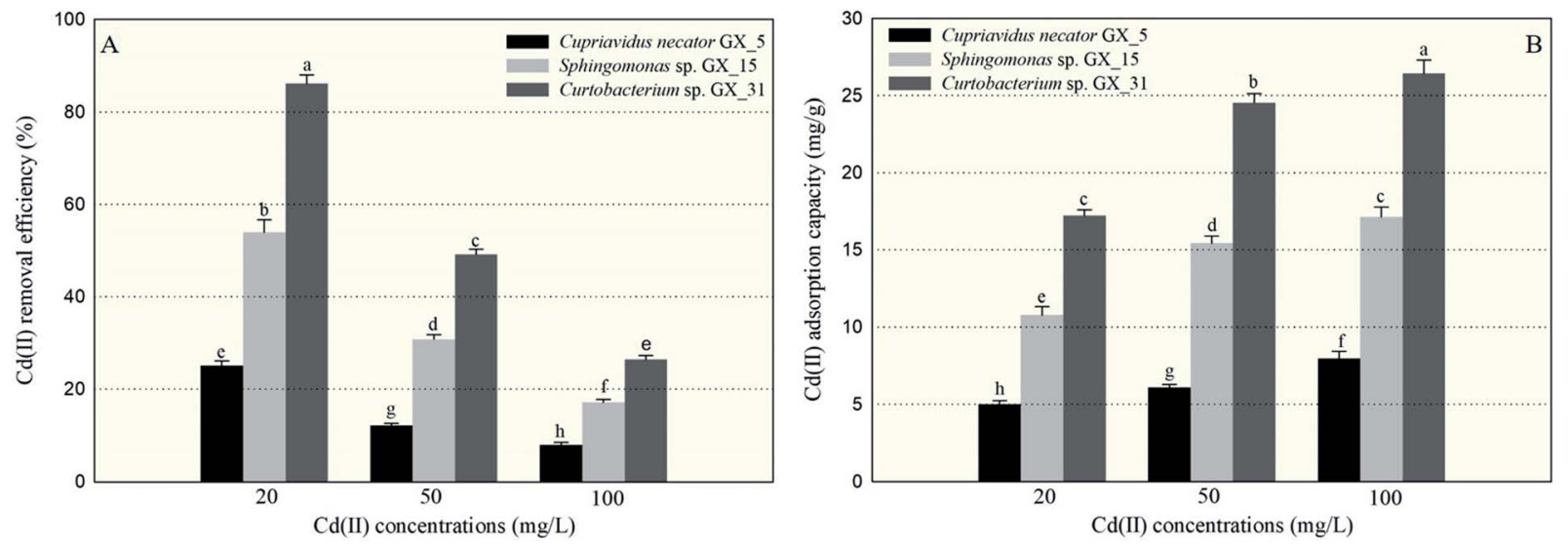

Fig. 1 The removal efficiency of $\mathrm{Cd}(\Perp)$ (A) and adsorption capacity of Cd(॥) (B) by Cupriavidus necator GX_5, Sphingomonas sp. GX_15, and Curtobacterium sp. GX_31 under 20,50, and $100 \mathrm{mg} \mathrm{l}^{-1}$ of initial Cd(॥) concentrations. 

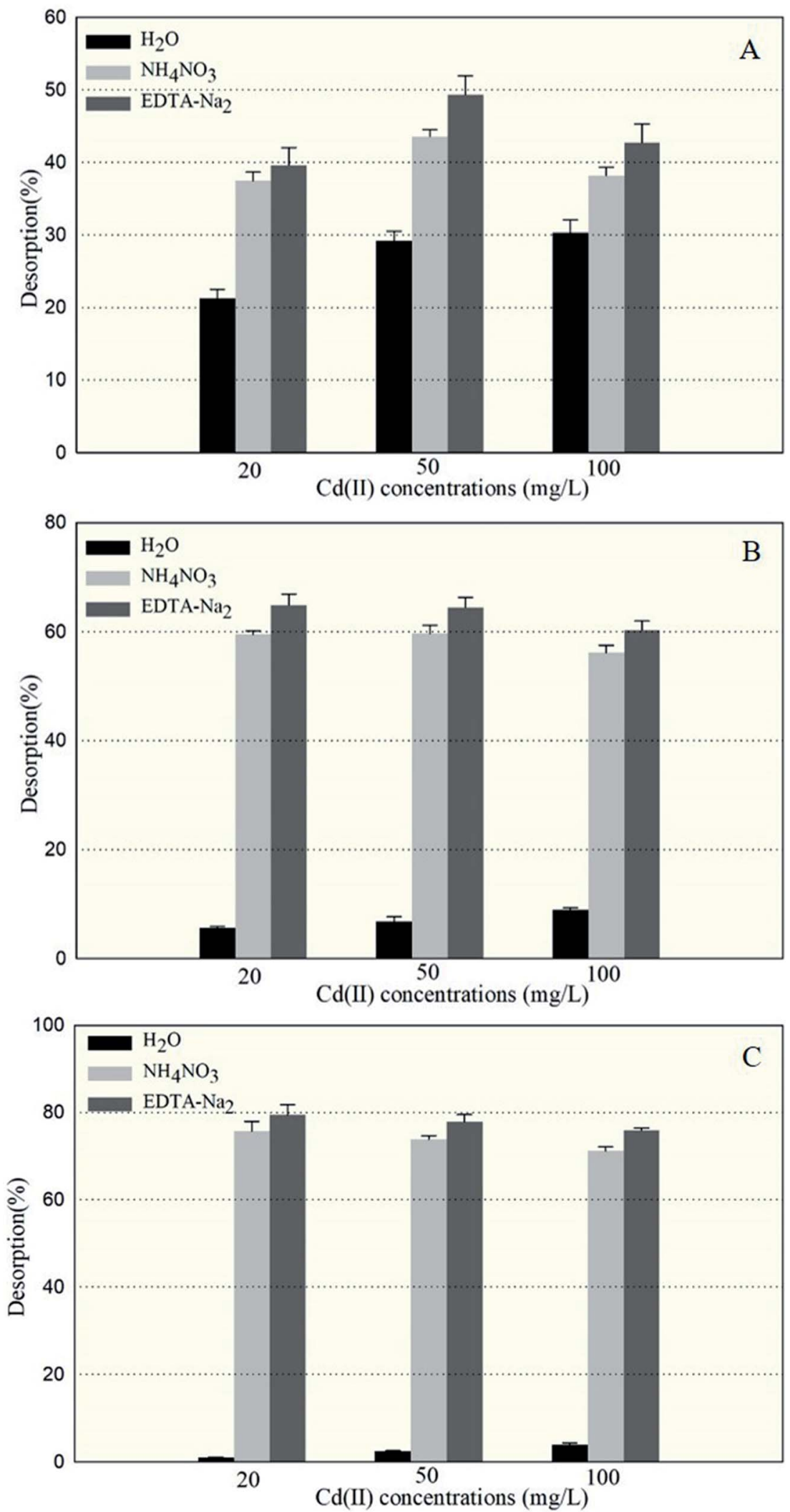

Fig. 2 The percentage of $\mathrm{Cd}(\Perp)$ desorbed from $\mathrm{Cd}(\Perp)$-loaded biomass of Cupriavidus necator GX_5 (A), Sphingomonas sp. GX_15 (B), and Curtobacterium sp. GX_31 (C), after treatment with $\mathrm{ddH}_{2} \mathrm{O}, 1.0 \mathrm{~mol} \mathrm{l}^{-1}$ of $\mathrm{NH}_{4} \mathrm{NO}_{3}$, and $0.1 \mathrm{~mol} \mathrm{l}^{-1}$ of EDTA-Na 2 , under 20,50 , and 100 mg l-1 initial $\mathrm{Cd}(\Perp)$ concentrations. 


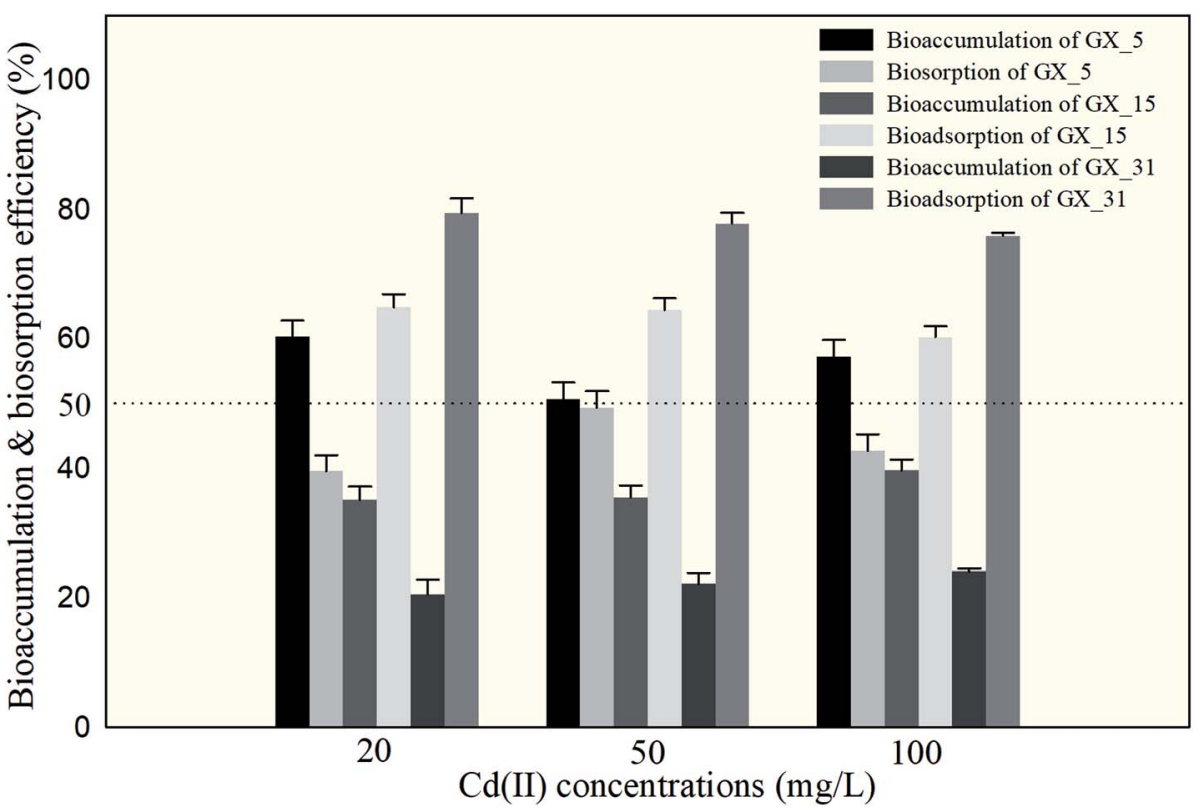

Fig. 3 Extracellular adsorption (biosorption) and intracellular accumulation (bioaccumulation) by Cupriavidus necator GX_5, Sphingomonas sp. GX_15, and Curtobacterium sp. GX_31 under 20,50, and $100 \mathrm{mg} \mathrm{l}^{-1}$ initial Cd(॥) concentrations.

Cd(II) adsorbed by GX_5 was desorbed by water, while 37.4843.58\% and 39.62-49.34\% was desorbed by $\mathrm{NH}_{4} \mathrm{NO}_{3}$ and EDTA$\mathrm{Na}_{2}$, respectively (Fig. 2A).

These results indicated that of the Cd(II) adsorbed by GX_5, 21.21-30.34\% was physically entrapped, $7.82-16.27 \%$ was held by ion exchange, $2.14-5.76 \%$ was complexed in functional groups (Fig. 2A), and 50.66-60.38\% was accumulated inside the cells (Fig. 3). On the contrary, for GX_15 and GX_31, 5.67-8.95\% and $0.97-3.93 \%$ was physically entrapped. This suggested that the bound Cd(II) was not easily released and the contribution of physical adsorption was minor. According to Fang et al., only $3.6 \%$ of $\mathrm{Cd}(\mathrm{II})$ was adsorbed physically by Spirulina $\mathrm{sp}^{23} \mathrm{~A}$ similar study was conducted by Chojnacka et al., who pointed out that the maximum contribution of physical adsorption by the blue-green algae Spirulina sp. was 3.7\%. ${ }^{35}$ Desorption rates for Cd(II) held by ion exchange for strains GX_15 and GX_31 were $47.14-53.81 \%$ and $67.28-74.73 \%$, respectively; rates for Cd(II) complexed in functional groups were $4.20-5.41 \%$ and $3.75-4.73 \%$, respectively (Fig. 2B and C); 35.11-39.71\% of Cd(II) was bioaccumulated in GX_5 and $20.55-24.07 \%$ in GX_15 (Fig. 3).

As these figures show, regardless of initial Cd(II) concentrations, the dominant mechanism for Cd(II) adsorption was bioaccumulation (intercellular accumulation) (50.66-60.38\%) for GX_5, while the dominant adsorption mechanisms were both biosorptions (extracellular adsorptions) (60.29-64.89\% for GX_15 and 75.93-79.45\% for GX_31) (Fig. 3). It is obvious that the biosorption mechanism of GX_5 is more prone to physical entrapment (21.20-30.33\%), while those of GX_15 and GX_31 tend toward ion exchange (47.14-53.81\% and $67.28-74.73 \%$, respectively). Adsorption mechanisms differed due to varying compositions and structures in bacterial cell walls. ${ }^{25}$ Another reason for adsorption mechanisms differing might be that exclusion mechanisms lead to Cd(II) being excreted from inside the cell and improving surface binding via metal-exporting proteins. ${ }^{36}$ Some researchers have concluded that the increase in surface adsorption might be a result of extracellular polymeric substances protecting cells from Cd(II) toxicity. ${ }^{21,37}$

The result was different from that obtained by Huang et al., who illustrated that intracellular accumulation is the main adsorption mechanism given lower metal concentrations and extracellular adsorption is the main adsorption mechanism at higher concentrations. ${ }^{\mathbf{1 1}}$ Due to variance in experimental conditions and analytical methods, it is inappropriate to compare adsorption mechanisms between researchers. ${ }^{38-41}$ However, although study results may not be directly comparable, we can be sure that strains GX_5, GX_15, and GX_31 show different Cd(II) adsorption mechanisms and capacities. Meanwhile, bioaccumulation and biosorption were verified by SEMEDX, TEM, and FTIR spectroscopy, which will be discussed in the following sections.

\subsection{SEM-EDX and TEM analysis}

To improve understanding of the mechanisms of $\mathrm{Cd}(\mathrm{II})$ interactions with microbes, SEM-EDX and TEM were performed. Cell surfaces of GX_5, GX_15, and GX_31 were all observed to be rod shapes with clear boundary before adsorption (Fig. 4A-a, Ba and C-a). There were no obvious changes in morphology of these strains after interaction with $\mathrm{Cd}$ (II) at a concentration of $20 \mathrm{mg} \mathrm{l}^{-1}$ (Fig. 4A-b, B-b and C-b). However, their surfaces became rough and were covered by sediments after the reaction; this effect was yet more evident when bacterial cells were exposed to $100 \mathrm{mg} \mathrm{l}^{-1} \mathrm{Cd}$ (II) (Fig. 4A-d, B-d and C-d). Changes in cell morphology could be explained as a protective mechanism responding to a stressful environment, which has previously been reported. ${ }^{\mathbf{4 2 , 4 3}}$ Moreover, for strain GX_15, cells appeared to aggregate after reaction with $\mathrm{Cd}(\mathrm{II})$, an effect which Fig. 4B-c and 

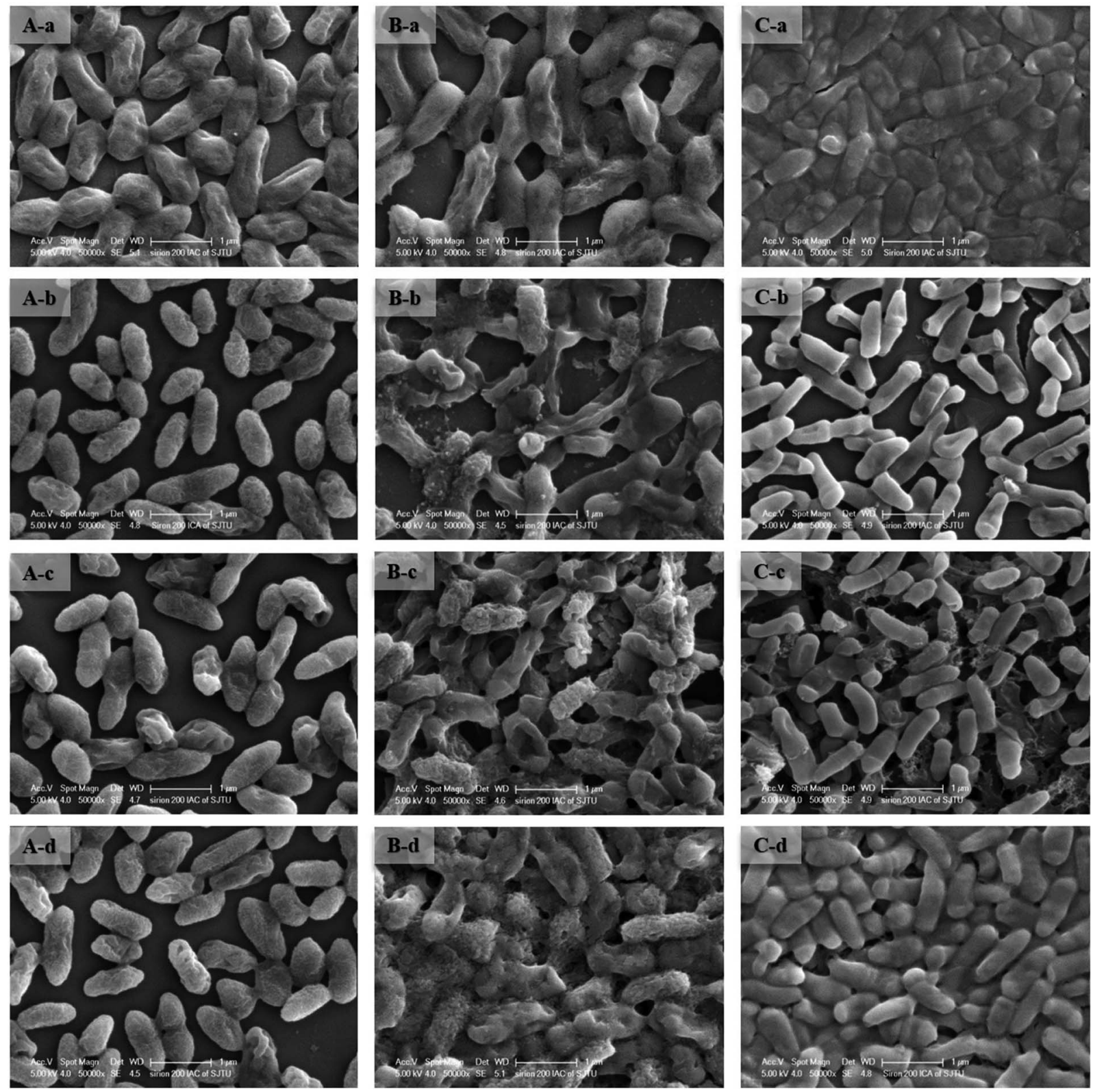

Fig. 4 SEM images of Cupriavidus necator GX_5 (A), Sphingomonas sp. GX_15 (B), and Curtobacterium sp. GX_31 (C) under different initial Cd(॥) concentrations ((a) $0 \mathrm{mg} \mathrm{l}^{-1}$ of $\mathrm{Cd}(॥)$; (b) $20 \mathrm{mg} \mathrm{l}^{-1}$ of $\mathrm{Cd}(॥)$; (c) $50 \mathrm{mg} \mathrm{l}^{-1}$ of $\mathrm{Cd}(॥)$; and (d) $100 \mathrm{mg} \mathrm{l}^{-1}$ of $\mathrm{Cd}(॥)$ ).

B-d show to be especially pronounced. Some floccus precipitation was found on the surface of GX_15 (Fig. 4B-b, B-c and B-d). Aggregation and precipitation might be caused by extracellular polymeric substances, which had an important role in binding heavy metals..$^{30} \mathrm{EDX}$ is a useful tool for chemical and elemental analysis of biosorbents and has been extensively applied. ${ }^{44}$ EDX spectra recorded the signals of carbon, nitrogen, and oxygen, which were likely in polysaccharides and proteins of the biosorbents (Fig. S1†). Unloaded biomass showed no Cd(II) signals in the EDX spectra, but signals could be observed after Cd(II) exposure, revealing the presence of $\mathrm{Cd}(\mathrm{II})$ in the cell after adsorption (Fig. S1 $\dagger$ ). However, EDX spectra could only determine the presence or absence of $\mathrm{Cd}(\mathrm{II})$ on the biomass qualitatively, not quantitatively.
Although most heavy metals are not essential to bacteria, some of them can cross the cell membrane and enter the cells via a range of processes. ${ }^{45}$ Therefore, TEM analysis of strains was conducted to intuitively show the effects of metal concentrations on cells. As shown in Fig. 5A-a, B-a and C-a, the cells were intact, the contents were identically dispersed in the cells, and the cell wall could be clearly distinguished from cytoplasm. With increased initial $\mathrm{Cd}$ (II) concentrations, the cell walls became unclear and vague and it was hard to tell the cell wall from cytoplasm (Fig. 5A-b, A-c, B-b, B-c, C-b and C-c). This phenomenon was especially evident given a $\mathrm{Cd}(\mathrm{II})$ concentration of $100 \mathrm{mg} \mathrm{l}^{-1}$ (Fig. 5A-d, B-d and C-d). Fig. 5B-c and B-d show that, under concentrations of 50 and $100 \mathrm{mg} \mathrm{l}^{-1}$ of Cd(II), some contents flowed out of the cells. This indicates that the cell walls 

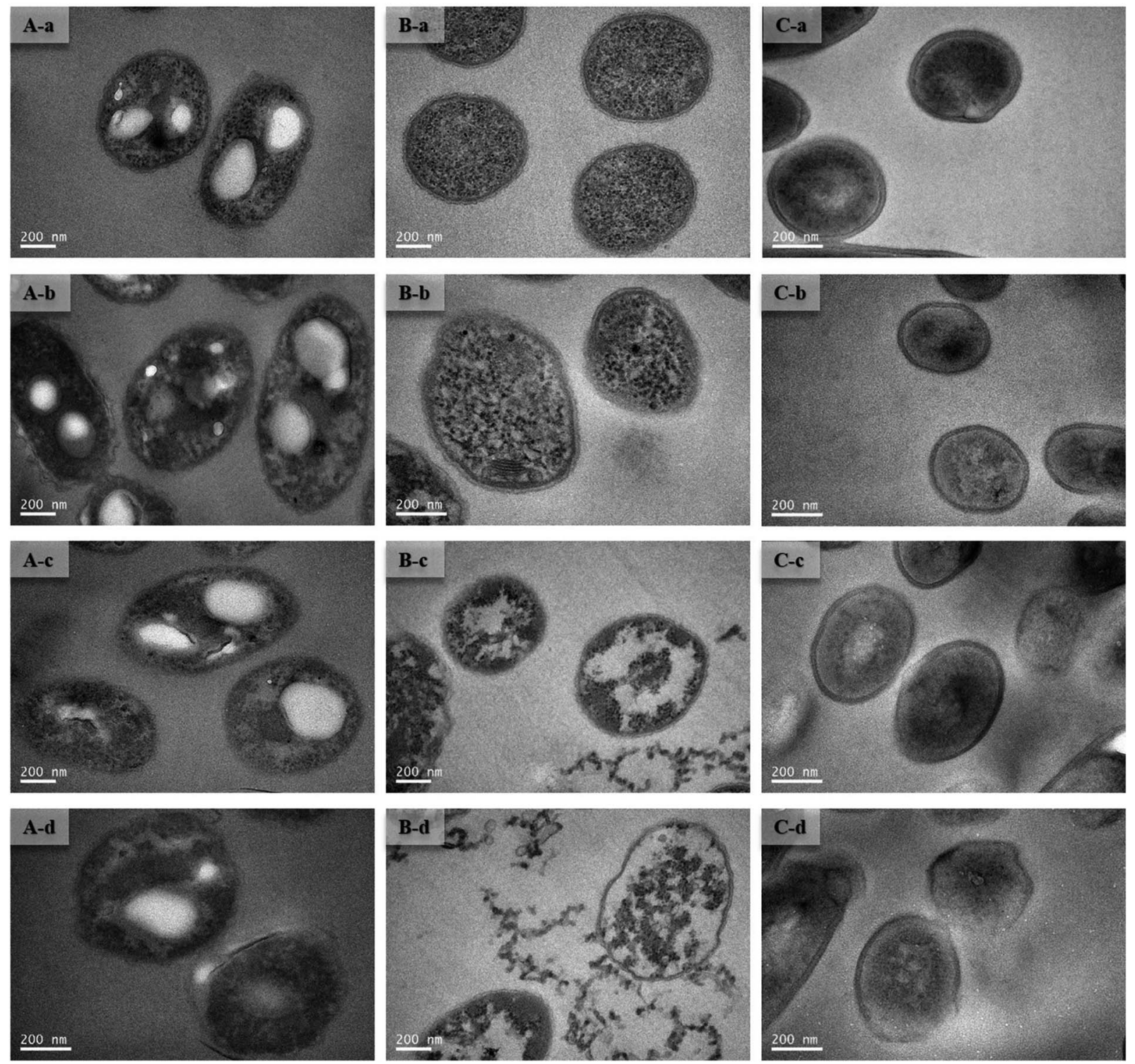

Fig. 5 TEM images of Cupriavidus necator GX_5 (A), Sphingomonas sp. GX_15 (B), and Curtobacterium sp. GX_31 (C) under different initial Cd(॥) concentrations ((a) $0 \mathrm{mg} \mathrm{l}^{-1}$ of $\mathrm{Cd}(॥)$; (b) $20 \mathrm{mg} \mathrm{l}^{-1}$ of $\mathrm{Cd}(॥)$; (c) $50 \mathrm{mg} \mathrm{l}^{-1}$ of $\mathrm{Cd}(॥)$; and (d) $100 \mathrm{mg} \mathrm{l}^{-1}$ of $\mathrm{Cd}($ II)).

of GX_15 were destroyed by high Cd(II) concentrations, and thus that GX_15 is more sensitive to Cd(II) than GX_5 and GX_31.

\subsection{FTIR spectra study}

To investigate possible interactions between $\mathrm{Cd}(\mathrm{II})$ and functional groups on the cell walls, the FTIR spectra of GX_5, GX_15, and GX_31 were recorded before and after Cd(II) adsorption. The pre-adsorption FTIR spectra revealed the presence of many functional groups on the cell surface, indicating the complex nature of the strains (Fig. 6A-a, B-a and C-a). Meanwhile, the IR spectra of GX_15 and GX_31 were similar to each other, but different from that of GX_5 (Fig. 6A-C).

Broad spectra bands were observed in the range of 3300$3500 \mathrm{~cm}^{-1}$, representing the stretching bond of the $-\mathrm{NH}$ from an amino group and a bonded hydroxyl group. ${ }^{46}$ After contact with $\mathrm{Cd}(\mathrm{II})$, the spectra had the tendency to shift to lower frequencies (Fig. 6A-C), an effect that was more evident for GX_31 (Fig. 6C).

The band around $2930 \mathrm{~cm}^{-1}$ corresponded to symmetrical - $\mathrm{CH}$ - vibration of $-\mathrm{CH}_{2}$ and $-\mathrm{CH}_{3}$ in lipids, ${ }^{47}$ which showed subtle changes after adsorption (Fig. 6). For strains GX_5 and GX_15, there were no changes at the band of $2850 \mathrm{~cm}^{-1}$, which corresponded to asymmetrical $-\mathrm{CH}$ - vibration in lipids. ${ }^{34}$ However, the adsorption peaks at $2850 \mathrm{~cm}^{-1}$ for GX_31 shifted from $2847.50 \mathrm{~cm}^{-1}$ to $2850.38 \mathrm{~cm}^{-1}\left(20 \mathrm{mg} \mathrm{l}^{-1} \mathrm{Cd}\right.$ (II)-loaded), $2851.41 \mathrm{~cm}^{-1}$ (50 $\mathrm{mg} \mathrm{l}^{-1} \mathrm{Cd}(\mathrm{II})$-loaded), and $2851.43 \mathrm{~cm}^{-1}$ (100 $\mathrm{mg} \mathrm{l}^{-1} \mathrm{Cd}(\mathrm{II})$-loaded) (Fig. 6C).

Carbonyl groups stretching vibration was prominent at $1741.17 \mathrm{~cm}^{-1}$ for strain GX_5 (Fig. 6A). ${ }^{48}$ After interaction with 20,50 , and $100 \mathrm{mg} \mathrm{l}^{-1}$ concentrations of $\mathrm{Cd}(\mathrm{II})$, the spectra of Cd(II)-loaded biomass demonstrated a clear shift of this peak to 


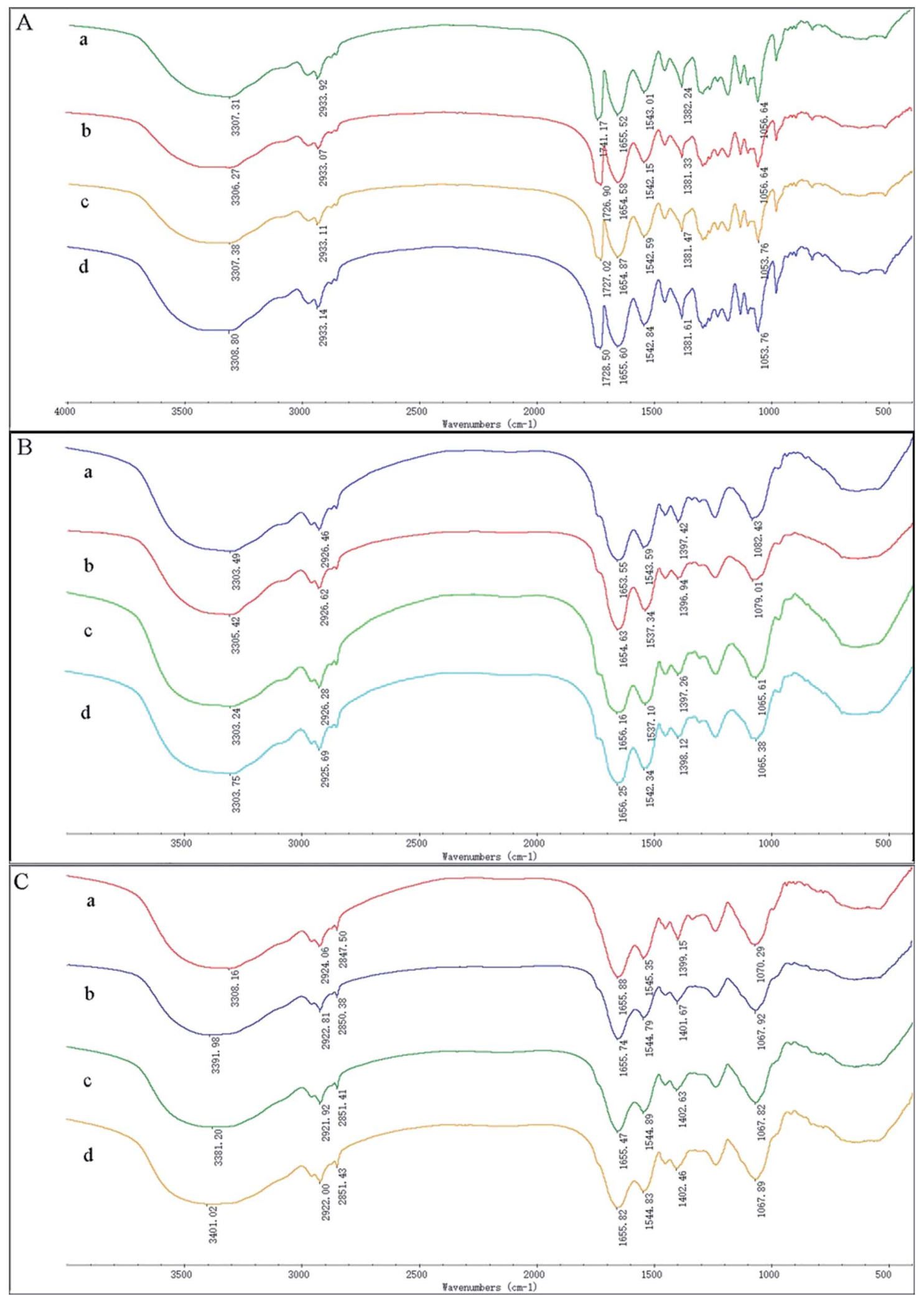

Fig. 6 FTIR images of Cupriavidus necator GX_5 (A), Sphingomonas sp. GX_15 (B), and Curtobacterium sp. GX_31 (C) under different initial Cd(॥) concentrations ((a) $0 \mathrm{mg} \mathrm{l}^{-1}$ of $\mathrm{Cd}(\Perp)$; (b) $20 \mathrm{mg} \mathrm{l}^{-1}$ of $\mathrm{Cd}(\Perp)$; (c) $50 \mathrm{mg} \mathrm{l}^{-1}$ of $\mathrm{Cd}(॥)$; and (d) $100 \mathrm{mg} \mathrm{l}^{-1}$ of $\mathrm{Cd}(॥)$ ).

$1726.90 \mathrm{~cm}^{-1}, 1727.02 \mathrm{~cm}^{-1}$, and $1728.50 \mathrm{~cm}^{-1}$, respectively. Strains GX_15 and GX_31 did not show any peak at this band (Fig. 6B and C).
The peaks between $1650 \mathrm{~cm}^{-1}$ and $1540 \mathrm{~cm}^{-1}$ could be assigned to amide groups in proteins. ${ }^{49}$ The typical amide I (-CO-) appeared at $1655.52 \mathrm{~cm}^{-1}, 1653.55 \mathrm{~cm}^{-1}$, and 
$1655.88 \mathrm{~cm}^{-1}$, respectively, for GX_5, GX_15 and GX_31; while the peaks at $1543.01 \mathrm{~cm}^{-1}, 1543.59 \mathrm{~cm}^{-1}$, and $1545.35 \mathrm{~cm}^{-1}$ were considered to be amide II $\left(-\mathrm{NH}^{-}\right)$. The spectra showed a minor shift of these two bands to $1654.58 \mathrm{~cm}^{-1}$ and $1655.47 \mathrm{~cm}^{-1}$ for GX_5 and $1542.15 \mathrm{~cm}^{-1}$ and $1544.79 \mathrm{~cm}^{-1}$ for GX_31 (Fig. 6A and C); for GX_15, the two bands shifted to $1656.25 \mathrm{~cm}^{-1}$ and $1537.34 \mathrm{~cm}^{-1}$ (Fig. 6B).

A minor peak shift at $1397.42 \mathrm{~cm}^{-1}$ to $1398.12 \mathrm{~cm}^{-1}$ for GX_15 (Fig. 6B), $1399.15 \mathrm{~cm}^{-1}$ to $1402.46 \mathrm{~cm}^{-1}$ for GX_31 (Fig. 6C), and $1382.24 \mathrm{~cm}^{-1}$ to $1381.33 \mathrm{~cm}^{-1}$ for GX_5 (Fig. 6A) indicated the role of carboxyl groups in Cd(II) binding. ${ }^{31,50}$ For GX_15, there existed a significant shift from $1082.43 \mathrm{~cm}^{-1}$ to $1065.38 \mathrm{~cm}^{-1}$, corresponding to the -CO- group vibration in the cyclic structure of carbohydrates. ${ }^{26}$ Meanwhile, a band at $1070.29 \mathrm{~cm}^{-1}$ shifted to $1067.82 \mathrm{~cm}^{-1}$ for GX_31, representing the -CO- groups as well. ${ }^{20}$ In the control spectra, the adsorption peak at $1056.64 \mathrm{~cm}^{-1}$ due to the phosphate groups was observed, ${ }^{38}$ and a shift of this peak to $1053.76 \mathrm{~cm}^{-1}$ (50 and $100 \mathrm{mg} \mathrm{l}^{-1} \mathrm{Cd}(\mathrm{II})$-loaded) (Fig. 6A) suggested the interaction of bound metals with phosphates.

After Cd(II) adsorption occurred, the overall IR spectra analysis indicated the involvement of functional groups such as hydroxyl, carbonyl, and carboxyl groups of saccharides; amino and amide groups of proteins; phosphate groups; and -COC- groups of carbohydrates in the interaction of $\mathrm{Cd}(\mathrm{II})$ with bacteria. Moreover, with increased initial metal concentrations, the differences between IR spectra for Cd(II)-free and for Cd(II)-loaded cells was more distinct.

\section{Conclusions}

Three cadmium-resistant PGPR, Cupriavidus necator GX_5, Sphingomonas sp. GX_15, and Curtobacterium sp. GX_31, were used to study bioaccumulation and biosorption mechanisms under different initial Cd(II) concentrations. Removal efficiency and adsorption capacity of the assessed PGPR can be ordered as GX_31 > GX_15 > GX_5. Strain GX_15 showed high potential (86.06\%) for $\mathrm{Cd}(\mathrm{II})$ remediation. Physical entrapment, ion exchange, and complexation were involved in biosorption processes. The dominant adsorption mechanism for GX_5 was bioaccumulation, while the dominant mechanisms for GX_15 and GX_31 were both biosorptions. The elucidation of the binding mechanisms could provide new perspectives of strains in practical bioremediation applications for heavy metals. However, more strains from different genera or even phyla are needed to be assessed for biosorption and bioaccumulation mechanisms under different metal concentrations and using various analysis methods.

\section{Conflicts of interest}

There is no conflict of interest and all the authors are interested to publish the manuscript.

\section{Acknowledgements}

This work was supported by Agriculture Committee of Shanghai (2014/5-2). We are thankful to MS Yao Han for SEM and EDX analysis, MS Yanhua Zhu and Ge Wang for TEM analysis, and Prof. Bangshang Zhu for FTIR spectra analysis (Instrumental Analysis Center of Shanghai Jiao Tong University, Shanghai, China).

\section{References}

1 Y. Wang, J. Shi, H. Wang, Q. Lin, X. Chen and Y. Chen, Ecotoxicol. Environ. Saf., 2007, 67, 75-81.

2 C. Xu, S. He, Y. Liu, W. Zhang and D. Lu, Chemosphere, 2017, 173, 622-629.

3 C. N. Mulligan, R. N. Yong and B. F. Gibbs, J. Hazard. Mater., 2001, 85, 145-163.

4 J. Wang and C. Chen, Biotechnol. Adv., 2009, 27, 195-226.

5 D. Prithviraj, K. Deboleena, N. Neelu, N. Noor, R. Aminur, K. Balasaheb and M. Abul, Ecotoxicol. Environ. Saf., 2014, 107, 260-268.

6 X. Xu, Z. Zhang, Q. Huang and W. Chen, Geomicrobiol. J., 2018, 35, 40-49.

7 B. Ye, Y. Luo, J. He, L. Sun, B. Long, Q. Liu, X. Yuan, P. Dai and J. Shi, Bioresour. Technol., 2018, 264, 206-210.

8 Y. Zhang, W. Liu, M. Xu, F. Zheng and M. Zhao, J. Hazard. Mater., 2010, 178, 1085-1093.

9 A. S. Ayangbenro and O. O. Babalola, Int. J. Environ. Res. Public Health, 2017, 14, 94.

10 T. Limcharoensuk, N. Sooksawat, A. Sumarnrote, T. Awutpet, M. Kruatrachue, P. Pokethitiyook and C. Auesukaree, Ecotoxicol. Environ. Saf., 2015, 122, 322-330.

11 F. Huang, C. Guo, G. Lu, X. Yi, L. Zhu and Z. Dang, Chemosphere, 2014, 109, 134-142.

12 J. Bai, X. Yang, R. Du, Y. Chen, S. Wang and R. Qiu, J. Environ. Sci., 2014, 26, 2056-2064.

13 Y. Li, Q. Yue and B. Gao, J. Hazard. Mater., 2010, 178, 455461.

14 T. Srinath, T. Verma, P. Ramteke and S. Garg, Chemosphere, 2002, 48, 427-435.

15 M. Pérez-Rama, E. Torres, C. Suárez, C. Herrero and J. Abalde, J. Environ. Manage., 2010, 91, 2045-2050.

16 G. M. Gadd, Experientia, 1990, 46, 834-840.

17 R. Chakravarty and P. C. Banerjee, Bioresour. Technol., 2012, 108, 176-183.

18 J. E. McLean, M. W. Pabst, C. D. Miller, C. O. Dimkpa and A. J. Anderson, Chemosphere, 2013, 91, 374-382.

19 V. I. Slaveykova, N. Parthasarathy, K. Dedieu and D. Toescher, Environ. Pollut., 2010, 158, 2561-2565.

20 Y. Lin, X. Wang, B. Wang, O. Mohamad and G. Wei, Ecotoxicol. Environ. Saf., 2012, 77, 7-17.

21 M. W. Pabst, C. D. Miller, C. O. Dimkpa, A. J. Anderson and J. E. McLean, Chemosphere, 2010, 81, 904-910.

22 M. Vargas-García, M. López, F. Suárez-Estrella and J. Moreno, Sci. Total Environ., 2012, 431, 62-67.

23 L. Fang, C. Zhou, P. Cai, W. Chen, X. Rong, K. Dai, W. Liang, J.-D. Gu and Q. Huang, J. Hazard. Mater., 2011, 190, 810-815.

24 V. Rajesh, A. S. K. Kumar and N. Rajesh, Chem. Eng. J., 2014, 235, 176-185.

25 L. Fang, P. Cai, W. Chen, W. Liang, Z. Hong and Q. Huang, Colloids Surf., A, 2009, 347, 50-55. 
26 E. Khadivinia, H. Sharafi, F. Hadi, H. S. Zahiri, S. Modiri, A. Tohidi, A. Mousavi, A. H. Salmanian and K. A. Noghabi, J. Ind. Eng. Chem., 2014, 20, 4304-4310.

27 A. K. Tyagi and A. Malik, Micron, 2010, 41, 797-805.

28 Y. Jin, X. Wang, T. Zang, Y. Hu, X. Hu, G. Ren, X. Xu and J. Qu, J. Microbiol. Biotechnol., 2016, 26, 1428-1438.

29 C. Sukumar, V. Janaki, S. Kamala-Kannan and K. Shanthi, Clean Technol. Environ. Policy, 2014, 16, 405-413.

30 Y. Yang, M. Hu, D. Zhou, W. Fan, X. Wang and M. Huo, RSC Adv., 2017, 7, 18793-18802.

31 P. Arivalagan, D. Singaraj, V. Haridass and T. Kaliannan, Ecol. Eng., 2014, 71, 728-735.

32 M. Oves, M. S. Khan and A. Zaidi, Saudi J. Biol. Sci., 2013, 20, 121-129.

33 P. Chakravarty, N. S. Sarma and H. Sarma, Chem. Eng. J., 2010, 162, 949-955.

34 N. Masoudzadeh, F. Zakeri, T. bagheri Lotfabad, H. Sharafi, F. Masoomi, H. S. Zahiri, G. Ahmadian and K. A. Noghabi, J. Hazard. Mater., 2011, 197, 190-198.

35 K. Chojnacka, A. Chojnacki and H. Gorecka, Chemosphere, 2005, 59, 75-84.

36 D. H. Nies, FEMS Microbiol. Rev., 2003, 27, 313-339.

37 M. Ueshima, B. R. Ginn, E. A. Haack, J. E. Szymanowski and J. B. Fein, Geochim. Cosmochim. Acta, 2008, 72, 5885-5895.

38 X. Li, C. Ding, J. Liao, T. Lan, F. Li, D. Zhang, J. Yang, Y. Yang, S. Luo and J. Tang, J. Environ. Radioact., 2014, 135, 6-12.

39 G. Ren, Y. Jin, C. Zhang, H. Gu and J. Qu, Ecotoxicol. Environ. Saf., 2015, 117, 141-148.
40 D. R. Shaw and J. Dussan, Water, Air, Soil Pollut., 2015, 226, 112.

41 H. Wang, A. McCarthney, X. Qiu and R. Zhao, Geomicrobiol. J., 2012, 29, 199-205.

42 R. Chakravarty and P. C. Banerjee, Extremophiles, 2008, 12, 279-284.

43 C. Nithya, B. Gnanalakshmi and S. K. Pandian, Mar. Environ. Res., 2011, 71, 283-294.

44 Q. Zhai, F. Tian, G. Wang, J. Zhao, X. Liu, K. Cross, H. Zhang, A. Narbad and W. Chen, RSC Adv., 2016, 6, 5990-5998.

45 T. Lan, Y. Feng, J. Liao, X. Li, C. Ding, D. Zhang, J. Yang, J. Zeng, Y. Yang and J. Tang, J. Environ. Radioact., 2014, 134, 6-13.

46 L. Fan, Z. Ma, J. Liang, H. Li, E. Wang and G. Wei, Bioresour. Technol., 2011, 102, 703-709.

47 D. Das, B. B. Salgaonkar, K. Mani and J. M. Braganca, Chemosphere, 2014, 112, 385-392.

48 T. Wang and H. Sun, Environ. Sci. Pollut. Res., 2013, 20, 74507463.

49 F. Masoumi, E. Khadivinia, L. Alidoust, Z. Mansourinejad, S. Shahryari, M. Safaei, A. Mousavi, A.-H. Salmanian, H. S. Zahiri and H. Vali, J. Environ. Chem. Eng., 2016, 4, 950-957.

50 S. S. Zamil, M. H. Choi, J. H. Song, H. Park, J. Xu, K.-W. Chi and S. C. Yoon, Appl. Microbiol. Biotechnol., 2008, 80, 531544. 